\title{
STUDI FENOMENOLOGI PENGALAMAN PERAWAT INSTALASI GAWAT DARURAT (IGD) DALAM MERAWAT PASIEN TERLANTAR PADA FASE END OF LIFE DI RSUD Dr. SAIFUL ANWAR MALANG Maria Imaculata Ose ${ }^{1}$, Retty Ratnawati $i^{2}$, Retno Lestari ${ }^{3}$ \\ ${ }^{1}$ Universitas Borneo Tarakan \\ ${ }^{2,3}$ Staf Pengajar Magister Keperawatan Fakultas Kedokteran Universitas Brawijaya ABSTRAK
}

Pasien terlantar dalam keadaan kritis yang memasuki fase End of Life sering dirawat di IGD. Kondisi tanpa ada keluarga yang mendampingi dan lingkungan IGD yang sibuk dan bising menjadi hambatan juga tantangan dalam perawatan End of Life. Perawatan pasien terlantar dalam tahap End of Life membutuhkan penanganan yang bertujuan memberikan rasa nyaman, ketenangan, kedekatan dukungan social. Penelitian ini bertujuan untuk mengeksplorasi pengalaman perawat dalam merawat pasien terlantar dalam fase End of Life di ruang IGD RSUD dr. Saiful Anwar Malang. Desain penelitian dengan metode kualitatif dengan pendekatan Fenomenologi interpretif, yang melibatkan 7 perawat IGD. Data dikumpulkan melalui Indepth interview dan dianalisis dengan menggunakan analisa tematik Braun \& Clark. Hasil penelitian menghasilkan 7 tema yaitu 1. merasakan hati tersentuh pada pasien terlantar menjelang ajal 2. Tidak membedakan perlakuan pada pasien terlantar dengan pasien lain yang menjelang ajal 3. Menghargai harkat dan martabat pasien 4. Memilih perawatan suportif sebagai tindakan terbaik 5 . Terpaksa meninggalkan pasien tanpa pendampingan spritual 6 . Mengalami konflik dalam menempatkan pasien terlantar yang menjelang ajal 7. Mengharapkan situasi lingkungan kerja yang mendukung. Kesimpulan adalah perawat bersikap profesional, menghormati harkat dan martabat dalam memberikan perawatan tanpa membedakan perlakuan dengan pasien lain yang menjelang ajal. Perasaan hati yang tersentuh muncul saat merawat pasien terlantar yang menjelang ajal tanpa didampingi keluarga. Perawatan End of Life lebih berfokus pada perawatan suportif, sedangkan dukungan spiritual tidak dapat diberikan di IGD karena karakteristik lingkungan yang sibuk dan lebih memprioritaskan pasien kritis. Hal ini menimbulkan konflik dan dilema bagi perawat sehingga diperlukan adanya ruangan khusus dan tim kerohanian untuk menyiapkan kematian yang damai dan bermartabat.

Kata Kunci: Pasien terlantar, End of Life, Perawatan Gawat Darurat.

\section{Abstract}

Homeless patients who are encountering the End of Life phase are regularly admitted to the emergency department. Barriers to treating these patients arise due to no family assistance and unconducive environment. Treatments given to the patients who are facing the End of Lifephase should be able to make the patients feel comfortable, calm, and socially supported. This research aimed to explore the experiences of the nurses who care for the homeless patients in the emergency department of RSUD dr. Saiful Anwar Malang. This research was designed qualitatively employing the interpretive phenomenological approach. There were seven nurses participating in this study. Data was obtained through an in-depthinterview and analyzed by the Braun \& Clark's thematic analysis. The results have successfully found seven themes: 1 . Nurses feel touched at the moment the patients are facing the dead 2. Nurses give mutual treatments to all patients, including the homeless 3. Nurses respect the homeless 4. Nurses prefer supportive treatments as the best intervention 5. Nurses have to leave the homeless without any spiritual assistance 6. Nurses face conflicts where to place the homeless 7. Nurses expect a conducive working environment. In conclusion the nurses maintained their professionalism, respected the homeless patients, gave mutual treatments to the patients. They felt touched because there was no family assisted the patients when they were struggling at the edge of their life. Treatments given to the patients at the End of Life phase were focused more on supportive treatments. No spiritual assistance could be provided by the emergency department due to busy environment and priority given to other dying patients. These have become problematic for the nurses. So, the availability of rooms for the homeless and spiritual teams can be helpful to prepare the patients die in peace and dignity.

Keywords: Homeless Patients, End of Life, Emergency of Nursing.

Jurnal Ilmu Keperawatan, Vol:4, No.2; Korespondensi : Maria Imaculata Ose. Universitas Borneo Tarakan. Alamat: Jl. S. Mahakam Asmil Kompi C 613 Kampung 4 Tarakan.Email. onijuntak@gmail.com. No. Hp 085652149185 


\section{PENDAHULUAN}

Instalasi Gawat Darurat (IGD) merupakan unit pertama dalam pelayanan kesehatan di Rumah Sakit yang memprioritaskan pasien sesuai dengan tingkat keadaan gawat darurat. Dalam hal ini perawat dituntut untuk mampu dalam berkomunikasi dan memberikan pelayanan secara profesional. Kondisi pasien yang datang ke IGD bervariasi, baik yang mengancam jiwa maupun yang menjelang ajal. Pasien dengan kondisi mengancam nyawa berfokus pada tindakan resusitasi, sedangkan pada pasien yang menjelang ajal lebih berfokus pada perawatan End of Life.

End of Life Care diberikan pada pasien yang menjelang meninggal atau fase kritis dengan menerapkan Teori Peaceful End of Life. (Ruland \& Moore, 1998 dalam Aligood \& Tomey, 2014). Teori iniyang mencakup konsep persiapan yang baik dalam menghadapi kematian. Intervensi dalam konsep teori ini dilakukan yang bertujuan pasien merasa bebas dari rasa nyeri, merasa kenyamanan, merasa dihargai, dihormati dan berada dalam kedamaian dan ketenangan juga merasa dekat dengan orang dirawatnya.

Beckstrand et al (2015) menyebutkan perawat mengalami hambatan dalam memberikan pelayanan End of Lifeyang baik pada pasien yang tidak memiliki identitas. Selain itu perawatan End of Life menjadi sulit dilakukan dan menimbulkan permasalahan bagi perawat, terutama jika tidak ada yang mendampingi. IGD RSUD dr. Saiful Anwar cukup banyak pasien terlantar. Berdasarkan Laporan Tahunan RSUD dr. Saiful Anwar (2014) di IGD menerima pasien terlantar pada tahun 2012 sebanyak 69 orang, pada tahun 2013 sebanyak 55 orang pasien terlantar, dan tahun 2014 mengalami peningkatan 75 orang pasien yang terlantar.

Berdasarkan pengamatan peneliti pada bulan desember 2015 di IGD RSUD dr.Saiful Anwar, perawat tidak dapat maksimal menemani dan selalu berada mendampingi disisi pasien terlantar ini. Persepsi perawat pada pasien terlantar dengan End of Life bukanlah pasien yang prioritas lagi. Banyak pasien lain dalam kondisi emergency yang membutuhkan penanganan sehingga perawat tidak memiliki banyak waktu untuk fokus membantu pasien terlantar melewati fase End of Life.

Wolf, (2015) menyebutkan bahwa perawat di IGD sudah menyediakan End of Life Care, dan perawat mengakui sudah menerapkan End of Life Care namun terdapat keterbatasan dalam pelaksanaan fase End of Life meliputi beberapa hal yaitu pengalaman perawat, dan pengetahuan perawat, persepsi perawat, jumlah perawat saat menghadapi pasien dengan kondisi yang kritis. IGD merupakan lingkungan yang sibuk, bising dan memiliki privasi yang sangat rendah. Kondisi ini menyebabkan pasien terlantar tidak 
mendapatkan perawatan End of Life. Hal ini sangat bertolak belakang dengan yang dibutuhkan untuk perawatan pasien terlantar dalam tahap End of Life, yang membutuhkan penanganan yang bertujuan untuk memberikan rasa nyaman, ketenangan, kedekatan dukungan sosial. Hal ini sejalan dengan penelitian yang dilakukan oleh Beckstand et al (2015) yang menyebutkan IGD merupakan bukan tempat yang ideal saat menghadapi kematian.

Hasil wawancara pada beberapa perawat IGD RSUD dr.Saiful Anwar menyatakan bahwa pasien terlantar yang menjelang ajal biasanya sendiri tanpa ada yang mendampingi menimbulkan rasa keprihatinan oleh perawat. Tantangan lain dalam pelaksanaan End of Life yaitu kurangnya staf, kurangnya dukungan sosial (penyediaan tokoh agama, dukungan keluarga), waktu, dan tidak ada area khusus untuk pasien terlantar yang menjelang ajal.

Penelitian ini bertujuan melihat pengalaman perawat IGD merawat pasien terlantar dalam fase End of Life. Adanya kunjungan pasien terlantar dalam fase End of Life yang tidak memiliki keluarga sehingga perawat memiliki tanggung jawab dalam mendampingi pasien terlantar di IGD. Kondisi IGD yang mengambarkan lingkungan perawatan yang sibuk dan intensitas kerja yang cepat. Penelitian dan literatur terkait dengan pembahasan mengenai pengalaman perawat yang berkerja di IGD dalam rawat pasien terlantar dengan fase End of Life belum banyak diuraikan secara komprehensif dan mendalam, sehingga eksplorasi dalam terhadap pengalaman dan makna pengalaman IGD dalam merawat pasien terlantar dengan fase End of Life penting di lakukan.

\section{METODE}

Penelitian ini merupakan penelitian kualitatif dengan pendekatan fenomenologi iinterpretif. Partisipan dalam penelitian ini adalah perawat yang berkerja di ruang IGD RSUD dr. Saiful Anwar.Tahap pemilihan partisipan dengan teknik purposive sampling berdasarkan kriteria inkulsi dan memilih partisipan yang sudah dikenal oleh peneliti, dengan pertimbangan agar dalam pengambilan data dan Indepth interview partisipan tidak merasa canggung, dan kaku serta mendapatkan informasi yang lebih mendalam. Adapun kriteria partisipan adalah: (1) Perawat yang memiliki pengalaman kerja 8-19 tahun di ruang Critical Care IGD RSUD dr.Saiful Anwar, (2) Perawat yang memiliki pengalaman pengalaman merawat pasien terlantar pada fase End of Life (3) Pendidikan partisipan D3 keperawatan-S1 Keperawatan (4) Dalam keadaan sehat secara fisik, (5) Bersedia sebagai partisipan dengan menandatangani surat kesediaan menjadi partisipan. Proses seleksi terhadap partisipan diawali dengan 
peneliti bertemu Kepala Perawatan ruang Critical Care kemudian menjelaskan tujuan dari penelitian. Pengambilan data dimulai dari kepala ruangan sebagai partisipan kunci, selanjutnya dikembangkan ke partisipan lainnya. Pada penelitian ini, saturasi data dicapai pada wawancara partisipan ke tujuh. Data dikumpulkan melalui wawancara mendalam(Indepth interview)dengan pertanyaan terbuka dan dikembangkan oleh peneliti.Analisis data dilakukan dengan menggunakan Analisa tematik Braun \& Clark yang terdiri dari 6 tahapan.Penelitian ini telah mendapatkan laik etik di RSUD dr. Saiful Anwar

\section{HASIL}

Hasil penelitian ini menemukan ada 8 tema berdasarkan analisis tematik Braun \&Clack (2006) yang dilakukan. Delapan tema yang dihasilkan dalam penelitian ini mengambarkan pengalaman perawat IGD merawat pasien terlantar dalam fase End of Life yaitu1. Merasakan hati tersentuh pada pasien terlantar menjelang ajal $\quad 2$. Tidak membedakan perlakuan pada pasien terlantar dengan pasien lain yang menjelang ajal 3 . Menghargai harkat dan martabat pasien 4 . Memastikan tidak ada kecurangan pemberian nota dinas 5. Memilih perawatan suportif sebagai tindakan terbaik 6. Terpaksa meninggalkan pasien tanpa pendampingan spritual 7. Mengalami konflik dalam menempatkan pasien terlantar yang menjelang ajal 8. Mengharapkan situasi lingkungan kerja yang mendukung.

\section{Tema Merasa hati tersentuh pada pasien terlantar menjelang ajal}

Merasa kasihan mengandung makna rasa iba hati dan menyatakan rasa belas kasih. Merasa kasihan terbangun dari perasaan kasihan, empati, iba dan rasa penyesalan. Ungkapan perasaan kasihan partisipan sebagai berikut:

".....yah aslinya dilema di sini memandang gak keluarganya itukan kasihan sebenarnya..." (P3) “....kalau perasaan kasihan pasti ada .. yah terbentur juga .. (P4)

" ....yang terlintas pasti empati itu yah ada .. (P4))

" ...ehm.... kasihan yah... apalagi yang tidak ada keluarganya..."(P7)

Ungkapan partisipan diatas dapat disimpulkan bahwa partisipan tersebut merasakan tersentuh, iba, rasa belas kasih ketika melihat dan merawat pasien-pasien terlantar yang tidak ada keluarganya dengan kondisi yang menjelang ajal.

\section{Tema Tidak membedakan perlakuan pada pasien terlantar dengan pasien lain yang menjelang ajal.}

Perlakuan menjadi perbuatan yang dikenakan terhadap sesuatu atau orang lain. Tidak membedakan perlakuan pada pasien terlantar 
dengan pasien lain yang menjelang ajal mengandung makna kontekstual perawat memberikan hak dan perlakuan yang sama bagi setiap pasien yang datang ke IGD walaupun pasien tersebut tidak memiliki keluarga. Walaupun pasien terlantar tidak memiliki keluarga dan kondisi yang sangat memprihatikan dari segi hygiene namun secara psikologis perawat tidak membedakanbedakan pasien dari sisi terlantar maupun tidak terlantar.

"..Sama.... gak ada bedanya antara telantar dan tidak terlantar...."(P1) "...jadi kalau saya pribadi tidak ada perbedaan pada pasien terlantar yang kritis .."(P7)

"...gak memperlakukan lebih.. menurut saya sesuai dengan kebutuhnya...saya kira gak ada sih bedanya perlakuan .."(P5)

\section{Tema Menghargai Harkat dan Martabat pasien terlantar}

Dari tema ini dibangun dari subtema mengupayakan memberikan perawatan menjelang ajal yang baik dan bermartabat. Mengupayakan memberikan perawatan menjelang ajal yang baik dan bermartabat mengandung arti melakukan usaha perawatan menjelang ajal yang baik dengan memperlakukan pasien terlantar sebagai seseorang dengan manusiawi. Pasien terlantar tetaplah seorang manusia seutuhnya yang mana tetap wajib mendapatkan perlakuan yang layak. Hal ini diungkapkan oleh partisipan :

"..yah aslinya dilema di sini memandang itukan kasihan sebenarnya cuman mr.x ..mr.x jugakan manusia .."(P1)

“...Mr $x$ dipandang sebagai manusia......mr.x kan manusia .." (P3)

“..sama-sama manusia .. terlantar atau tidak terlantar sama saja .."(P5) Selain memandang pasien terlantar sebagai seorang manusia seutuhnya, sikap berusaha memberikan pelayanan secara manusiawi pada pasien terlantar, perawat memposisikan seandainya pasien sebagai keluarganya. Hal ini menjadi suatu alasan kuat untuk berusaha memberikan pelayanan yang layak, dalam fase menjelang ajal.

“.......andaikan itu keluarga saya yang diposisi itu .. saya tidak bisa melakukan tindakan apa-apa ..makanya saya tetap melakukan yang terbaik ...."(P4)

\section{Tema memilih perawatan suportif sebagai} tindakan terbaik

Perawatan suportif menjadi tindakan yang terbaik bagi pasien-pasien yang menjelang ajal. Perawatan suportif mengandung makna perawatan yang diberikan setelah tindakan resusitasi dan usaha komprehensif dinyatakan 
dan ditentukan tidak berhasil. Usaha suportif adalah perawatan lanjutan pada pasien tanpa melakukan intubasi dan pembukaan jalan nafas secara non-invasif. Pasien yang menjelang ajal perawatannya lebih berfokus pada kebutuhan fisik dan kebutuhan dasar. Perawatan suportif dalam pemenuhan kebutuhan dasar meliputi pemberiaan oksigen, pemberiaan cairan, obat-obatan antinyeri.

“...Kalau perawatan...... yang menjelang ajal harus di ini ... gak .. jadi itu hanya istilah secara umum-umum... sama saja .. secara medis itu atau kesehatan itu yah sudah kita.. sudah melakukan ini prosedurnya, obat-obatnya sudah masuk... seperti itu oksigen, cairan ini tetap kita berikan......"(P3)

“...kalau saya oksigen tidak stop, infus tetap jalan tapi tidak ada tindakan yang lain ... yah sudah ... sudah terpasang itu kita tidak melepas itu ... berarti alat yang terpasang pada saat resusitasi, sebelum resusitasinya dinyatakan gagal yah sudah dibiarkan saja sampai meninggal ... "(P2)

\section{Tema Terpaksa meninggalkan pasien tanpa}

\section{pendampingan spiritual}

Meninggalkan pasien yang terlantar menjelang ajal ketika ada pasien kritis yang membutuhkan penanganan, menjadi pilihan yang dilakukan oleh partisipan, memilih pasien yang prioritas harapan hidup yang lebih tinggi.Tema terpaksa meninggalkan pasien tanpa pendampingan spiritual dibangun dari subtema lebih memprioritas pasien yang harapan hidup lebih tinggi, tidak mampu melakukan pendampingan spiritual dan mengalami ketidakseimbangan antara beban kerja dan tenaga perawat.

Perawat IGD lebih memprioritas pasien yang harapan hidup lebih tinggi. Hal ini seperti yang diungkapkan oleh partisipan:

"Kalau ada pasien lain yang gawat.. ya prioritas tetap pada pasien yang hidup dulu .... kalau yang pertama kita kepentingannya menyelamatkan nyawa .. $(P 2)^{\prime \prime}$

“..... kita memprioritaskan apa yang masih bisa kita dilakukan dengan pasien yang lain ... dibanding dengan pasien terminal" (P4)

"kalau saya secara pribadi sendiri ..itu saya yang mendominakan pasien yang belum terminal.."(P6)

"kita secara psikologis kita meningkat yang harapan hidupannya lebih tinggi .."(P6)

“... disini banyak pasien ..kalau ada kondisi yang gawat lainnya tentu saja yang hidup dulu,.. tetap yang hidup dulu ...... kalau penyelamatan nyawa itu utama, kemudian nanti baru menyiapkan pasien yang terlantar untuk berangkat 
dengan tenang" (P3)

Dukungan spiritual ini menjadi bagian dalam pemberian pelayanan pasien menjelang ajal. IGD RSUD dr. Saiful Anwar telah memiliki Standar Operasional Prosedur untuk Pelayanan Kerohanian terkait dengan pelayanan pasien yang menjelang ajal (terminal). Perawat belum dapat mengaplikasikan pelayanan kerohanian pada pasien terlantar karena banyaknya beban kerja dan kurangnya tenaga perawat. Namun apabila pasien tersebut memiliki keluarga maka perawat akan memfasilitasi keluarga untuk memberikan dukungan ke rohanian atau spiritual.

“...tetap mbak fasilitas keluarga .. bukan hanya memanggil keluarga .. tapi memberi kesempatan keluarga untuk memberikan dukungan kepada pasiennya .. kita sendiri kalau terlibat ke pasiennya saya kira gak.... Itu kalau ada keluarganya...(P2)

Belum adanya team kerohanian dan belum adanya tenaga rohaniawan yang membantu memberikan dukungan spiritual.

"Kalau di IGD ..selama di IGD sih saya belum pernah dikunjungi oleh petugas kerohanian.... mungkin yang belum kita punya itu adalah layanan kerohanian (P2).

“...pendampingan oleh rohaniwan kita hanya sebatas wacana..."(P1) “.....kalau sisi kerohaniannya protokolnya ada ... tapi aplikasinya disini belum berjalan....." (P6)

“.....tapi dalam SOP boleh didampingi oleh rohaniawan .. ustad.... tapi di rumah sakit ini belum ada tampaknya ..."(P6)

Perawat menyadari pasien terlantar juga harus mendapatkan dukungan spiritual dalam menghadapi ajal. Terbatasnya waktu, tingginya beban kerja dan tidak adanya team khusus kerohanian dalam pelaksanaan dukungan spiritual yang dilakukan perawat pada pasien yang menjelang ajal dilakukan dengan spontan dan situasional saat menghadapi pasien tersebut.

"......kalau saya pribadi seperti itu ... yang jelas dalam kita mimpin doa bukannya tidak mau atau tidak bisa yang jelas... banyak pekerjaan lain yang harus diselesaikan (P6)

"...cuman kalau masalah spritual itu yang kurang di kita ......"(P3)

“....misalnya mr.x datang gak ada keluarganya sudah gak sadar lagi .. masuk dengan trauma atau kadang dengan penyebab lain dan tidak didampingi keluarga yah .. setahu saya tidak pernah dilakukan"...nanti kalau kita mimpin doa nanti di komplainin yang lain... (P5)

“...Selama ini perawatan umum saja, belum ada perawatan secara khusus spritual yah hanya spontan aja .. tapi yah 
kadang-kadang

kita

mesti

ngomong..."(P1)

"...gak ada ... atau belum pernah ada kita

berikan dukungan spiritual....yah cuman

kalau secara spontan yah...."(P5)

Tugas perawat di IGD selain melakukan tindakan mandiri, perawat juga bertugas dalam kelengkapan administrasi dan kelengkapan dokumentasi pasien yang menjadi tanggung jawab perawat IGD..

"...kita harus di tuntut administrasi, kelengkapan dokumentasi, pasien yang akan pindah keruangan ... jika kita tidak mengerjakan itu .. maka IGD akan penuh ..." (P7)

“...tapi kan kita juga ada dibebani dengan target ..dibebani dengan mana yang harus kita prioritaskan... tergantung dari kondisi pasien.."(P4)

"...semuanya perawat jadi multi fungsi selama perawatan disini .. "(P6)

Peran perawat di IGD selain melaksanakan fungsi mandirinya, perawat juga melaksanakan tindakan kolaborasi dan kegiatan atas instruksi dari tenaga medis lainnya.

"..nanti kalau dokternya sudah mungkin gak bisa mengejar yah.... yang lebih dominan perawatnya.."(P2)

“... bukan kita tidak mau yah .. yang lain pasien juga banyak yang memerlukan .. mungkin juga dokternya memerlukan kita harus menginfus atau lainnya istilahnya

lebih membantu yang lain (P3)

Jumlah tenaga perawat dengan beban kerja yang tidak seimbang dirasakan oleh partisipan sehingga tidak mampu melakukan pendampingan secara maksimal. Kurangnya tenaga perawat mengurangi keterlibatan dalam pendampingan secara intens. Pendampingan dalam makna kontekstual yaitu memberikan dukungan secara emosional, sosial, kenyamanan juga memberikan perasaan ketenangan hati bagi pasien yang menghadapi fase menjelang ajal.

".. secara halnya petugasnya juganya kurang secara BOR .. pasiennya juga tidak wes karuan seperti itu ....ditambah lagi kondisi disini situasi yang sulit jumlah pasiennya 100, kita yang jaga cuman ber 4 .. tenaganya sangat jauh ".... dan memang di protokol didampingi seperti ini.. tapi kalau dalam aplikasinya kita kan minimal dari petugas kebutuhan yang diharapan kendalanya sumber dayanya minimal sekali .."(P3)

“...karena kan .. jumlahnya terbatas .. tenaga kesehatannya..beban kerja perawat sangat banyak .. jumlah pasiennya tidak sesuai .. ...perawatnya lebih sedikit dan tidak ideal ... " (P7) 


\section{Tema Mengalami konflik dalam menempatkan pasien terlantar yang menjelang ajal}

IGD RSUD dr. Saiful Anwar tidak memiliki ruangan khusus untuk pasien-pasien yang menjelang ajal. Seperti yang diungkap oleh partisipan dibawah ini

"...kalau ruangan khusus disini gak ada .. ruangannya yah general seperti $p 1, p 2$ dan P3 sebenarnya sih kalau idealnya, sangat tidak ideal .. ..." (P6)

“...kendalanya itu pasien P1 datang tempat penuh .. kita berbenturan yaitu, kalau mau mengeser .. sudah di label pasien menjelang ajal .. tidak ada tindakan tapi menunggu ajal tuh ...taruh ditempat yang agak kepinggir sedikit yang mungkin nanti dengan catatan tidak sampai melupakannya.." (P2)

Hambatan lain yang muncul yaitu dalam kesulitan menjaga dan mempertahankan privasi pasien. Banyaknya pasien yang tidak memiliki ruangan khusus untuk pasien yang menjelang ajal menjadi suatu kesulitan untuk menjaga dan mempertahankan privasi pada pasien tersebut. seperti yang diungkap oleh partisipan :

" ....karena saya sudah beberapa kali menemui eh .. apa yah .. sebelahnya tidak meninggal sebenarnya, meninggalnya jauh $P 1$, pasiennya di $\mathrm{p3}$
..... histeris pasiennya ..."(P2)

\section{Tema Mengharapkan situasi lingkungan kerja} yang mendukung.

Adanya team kerohanian yang diharapkan dapat lebih berperan dan berfokus dalam memberikan pendampingan dan dukungan spiritual pada pasien-pasien yang menjelang ajal terutama bagi pasien yang tidak memiliki dan didampingi oleh keluarga. Harapan ini di ungkapkan oleh partisipan sebagai berikut:

“.... tetap ada pendampingan dari pihak rumah sakit pada fase ajal itu harusnya ada team bimbingan rohani..."(P4)

“......pasien yang tidak ada keluarganya bisa kita lakukan dengan menjelang ajal harus ada team yang berperan...... harapannya...."(P3)

Harapan adanya sarana ruangan khusus untuk perawatan pasien-pasien yang menjelang ajal baik pasien terlantar maupun yang memiliki keluarga. Dengan adanya ruangan khusus diharapkan pasien mendapatkan suasana yang lebih nyaman, dan tenang.

“.... mungkin perlu dipikirkan atau disiapkan ruangan khusus untuk pasien yang menjelang ajal mau terlantar atau tidak, apa yah istilah ruangan khusus, semacam ruangan upacara khusus, ruangan kecil sehingga kalau itu ingin melakukan upacara dalam kecil-kecilan 
kita bisa......memfasilitasi atau mungkin ingin berdoa disana lebih privasi..."(P2)

“...harapan saya .. memang harus ada tempat.. kalau untuk IGD..... memang tempat pasien DNR itu harus ada ...oh iya kalau lingkungannya lebih tenang kan lebih enak membimbing.."(P3)

\section{PEMBAHASAN}

Perawat memiliki kecenderungan merasa hati tersentuh dan terharu pada pasien yang dirawat secara langsung. Pasien terlantar yang menjelang ajal hanya sendiri tanpa ada dukungan dan pendampingan dalam perawatannya. Hal ini menjadikan kecenderungan munculnya perubahan psikologis timbul perasaan tersentuh, mengalami suatu perasaan yang berbeda saat merawat pasien terlantar yang menjelang ajal, menjadi tersentuh, muncul perasaan kasihan, iba, empati dan rasa penyesalan karena tidak ada keluarga yang mendampingi dalam tahap akhir dalam kehidupan yang dirasakan oleh perawat. Hal ini sejalan dengan penelitian yang dilakukan oleh Enggune., et al 2014 yang menyebutkan bahwa perasaan empati dan perasaan sedih merupakan dampak dari seringnya merawat pasien yang meninggal dan merupakan suatu hal yang wajar. Fridh, Forsberg, \& Bergbom, (2009) menyebutkan bahwa pasien yang meninggal dalam keadaan tanpa didampingi oleh keluarga akan menjadikan suatu hal yang sangat menyedihkan.

Mengatasi perubahan psikologis yaitu dengan mengendalikan perasaan, dimana membedakan simpati empati, menyampingkan empati, tidak terpengaruh oleh perasaan. Pengendalian dan mengatasi perubahan psikologis yang dirasakan sangat perlu disadari oleh perawat IGD untuk tetap bersikap professional dalam melakukan perawatan pasien terlantar yang menjelang ajal. Bersikap professional dengan memberikan perawatan caring secara fisik, secara emosional dan psikologis. Hal ini sejalan dengan yang diungkapkan oleh Hudak \& Gallo (2010) yang menyatakan bahwa perawat peka dalam membangun rasa empati pada pasien, tapi bukan perawat yang kehilangan kendali.

Sikap menghargai harkat dan martabat menjadi bagian dalam perawatan pasien terlantar yang menjelang ajal. Watson (2010) menyebutkan perawat menunjukan nilai-nilai humanistic (rasa kemanusian) dengan nilai kebaikan, empati dan caring pada pasien dengan mengutamakan kepentingan pasien yang akan berdampak rasa kebahagian dan kepuasaan dari perawat tersebut.

Perawatan pasien terlantar yang menjelang ajal kondisi End of Life membutuhkan fokus memberikan perawatan suportif. Perawatan 
suportif yang diberikan yaitu perawatan lanjut kebutuhan dasar, memberikan kenyamanan dan mengobservasi juga memonitor pasien terlantar yang menjelang ajal. Bailey, Murphy, \& Porock(2011) menyebutkan pasien di IGD dengan perawatan suportif untuk mengontrol gejala. Situasi kerja yang kurang mendukung, terlebih di IGD pasien-pasien yang harapan hidupnya lebih tinggi menjadi prioritas. Kondisi Prioritas berdasarkan tingkat dan level kegawatan dari setiap pasien. Decker, lee, Morphet (2014) menyebutkan Situasi IGD yang sibuk, dengan banyaknya tuntutan, mungkin sulit untuk memberikan pendampingan kematian yang baik. Bailey, Murphy, \& Porock(2011) dan Chan (2011) menyebutkan bahwa pasien-pasien dengan resusistasi selalu didahului diatas perawatan End of Life. Ketidakmampuan perawat untuk mendampingi spiritual ini menimbulkan dilema bagi perawat saat disisi lain perawat menyadari kebutuhan spiritual bagi pasien namun disisi lain lingkungan kerja dan banyaknya tugas dan pasien lain yang membutuhkan perhatian dari perawat. Perawat memiliki peran dalam melakukan intervensi secara langsung atau mengatur akses untuk mendapatkan perawatan spiritual bagi pasien yang menjelang ajal. Tingginya tuntutan, dan kurangnya waktu mempengaruhi dan menjadi hambatan keterampilan interpersonal dalam penyediaan spritual dari seorang perawat untuk penyediaan perawatan menjelang kematian yang optimal

Penempatan ruangan menjadi suatu permasalahan yang terjadi di IGD, terbatasnya ruangan dengan jumlah pasien yang melebihi kapasitas area P1 maka mengeser pasien karena tidak adanya ruangan khusus untuk pasien yang menjelang ajal. Perawat mengalami kesulitan menjaga dan mempertahankan privasi pasien dan pasien lain karena ruangan yang menyatu dan terlihat oleh pasien lain menimbulkan dampak psikologis yang tidak kenyaman bagi pasien lain.Lingkungan kerja yang kondusif merupakan prasyarat perawat untuk menyediakan perawatan End of Life yang berkualitas. perawat sangat membutuhkan ruangan perawatan yang khusus untuk pasien yang menjelang aja. Perawatan pasien dalam tahap End of Life, yang membutuhkan penanganan yang bertujuan untuk memberikan rasa nyaman, ketenangan, kedekatan suport sosial (Beckstrand et.al, 2012, Decker, et.al, 2015).Perawatan pasien yang menjelang fase End of Life melibatkan berbagai displin yang meliputi pekerja sosial, ahli agama, perawat, dokter (dokter ahli atau dokter umum yang berfokus pada perawatan yang holistic meliputi fisik, emosional, sosial, dan spiritual. (Hockenberry \&Wilson, 2005). 
Hasil penelitian ini dapat digunakan sebagai sarana evaluasi pelayanan perawatan End of Life maupun perawatan pada pasien terlantar. Evaluasi yang dilakukan sebagai perbaikan dan penyempurnaan pelayanan End of Life. diharapkan dengan mempertimbangkan adanya team kerohanian dan team khusus yang berfokus untuk pendampingan, dan dukungan spiritual pada pasien terlantar yang menjelang ajal di IGD.

Penelitian ini memiliki keterbatasan, yaitu peneliti tidak mengeksplorasi terkait upaya kolaboratif perawat dengan dokter dan anggota lain dari tim perawatan kesehatan. Kolaborasi bagian dari tanggung jawab dalam merawat pasien. Fokus tenaga medis penanganan dan pengobatan pada pasien dengan harapan hidup yang lebih tinggi, sehingga tidak berperan secara nyata pada pasien dalam transisi pasien yang menjelang ajal dirumah Sakit RSUD dr. Saiful Anwar. Penelitian ini hanya dilakukan terbatas di satu rumah sakit yang tentunya memiliki perbedaan kebijakan dan keterkaitan dengan lembaga-lembaga yang berhubungan dengan kebijakan bagi pasien terlantar di rumah sakit yang lainnya. Sehingga hasilnya mungkin tidak

\section{DAFTAR PUSTAKA}

Alligood, M., \& Tomey, A. (2014). Nursing Theorist and Their Work. Sixth Edition. St dapat dijadikan gambaran kondisi IGD pada umumnya di Indonesia.

\section{KESIMPULAN}

Perawat tetap bersikap profesional menghormati harkat dan martabat pasien dalam memberikan perawatan. Konflik batin, emosi, perasaan hati tersentuh muncul dengan melihat kondisi pasien terlantar menjelang ajal.

Dukungan spiritual tidak dapat diberikan namun perawatan suportif menjadi bagian perawatan terbaik bagi pasien terlantar yang menjelang ajal. Tantangan dan hambatan dalam perawatan End of Life yaitu kondisi lingkungan kerja di IGD tidak adanya team kerohanian dan tidak adanya ruangan khusus untuk pasien yang End of Life. Selain itu pelayanan IGD yang lebih memprioritaskan pasien dengan kesempatan hidupnya lebih tinggi.

Adanya fasilitas ruangan yang khusus dan team kerohanian bagi pasien terlantar diharapkan dapat menyiapkan kematian yang damai dan bermartabat dengan tidak adanya perlakuan yang berbeda antara pasien terlantar dengan pasien lain yang menjelang ajal.

Louis Missoury : Mosby Elseveir.

Bailey, C., Murphy, R., \& Porock, D. (2011). 
Trajectories of end-of-life care in the emergency department. Annals of Emergency Medicine, 57(4), 362369.http://doi.org/10.1016/i.annemergmed.2 $\underline{010.10 .010}$

Beckstrand., et, al. (2015). Rural Emergency Nurse's End of Life care obstacle experiences: stories from the last frontier. Journal Of Emergency Nursing. 19

Braun, V \& Clark, V. (2006). Using Thematic Analysis in Psychologi. Qualitative Research in Psychology 3 (77-101).

Chan, G. K. (2011). Trajectories of Approaching Death in the Emergency Department: Clinician Narratives of Patient Transitions to the End of Life. Journal of Pain and Symptom Management, 42(6), 864-881. http://doi.org/10.1016/j.jpainsymman.20 11.

Decker, K., Lee, S., \& Morphet, J. (2015). The experiences of emergency nurses in providing end-of-life care to patients in the emergency department.

Ebta Setiawan. Kamus Besar Bahasa Indonesia Online. 2012-2016 versi 1.9: Badan Pengembangan dan Pembinaan
Bahasa, Kemdikbud (Pusat Bahasa).

Enggune, M., Ibrahim, K., \& Agustina, H. R. (2014). Persepsi Perawat Neurosurgical Critical Care Unitterhadap Perawatan Pasien Menjelang Ajal.Jurnal Keperawatan Padjadjaran, 2(1).

Fridh, I., Forsberg, A., \& Bergbom, I. (2009). Doing one's utmost: Nurses' descriptions of caring for dying patients in an intensive care environment. Intensive and Critical Care Nursing, 25(5), 233-241.

Hudak, C., \& Gallo, B. (2010). Keperawatan kritis pendekatan holistik (Edisi 6. Vol. 1). Jakarta: Buku Kedokteran EGC. (Hockenberry \&Wilson, 2005)

Laporan Tahunan RSUD dr. Saiful Anwar (2014)

Wolf, L,. A., Altair M. D, et al. (2015). Exploring the management of death: Emergency nurses' perceptions of Challenges and facilitators in the Provision of end-of-life care in the Emergency department. Journal of Emergency Nursing. 41 (5) : e23-e33

Watson, J (2010). Caring science and the next decade of holistic healing:transforming self and system from inside out. 